\title{
Long term supply elasticities: a case study for Finland ${ }^{1}$
}

\author{
LAURI KETTUNEN \\ Agricultural Economics Research Institute, Luutnantintie 13, \\ SF-00410 Helsinki
}

\begin{abstract}
Long term supply elasticities for basic agricultural products are needed for forecasting and planning of agricultural production. Despite many econometric studies on supply elasticities in Finland, so far no coherent analysis covering all products has been made. This shortcoming is the background for this study.

Ordinary least squares were first used to estimate the elasticities, but since the residuals were in many cases autocorrelated, autoregressive models were also applied. The fit of the models did not improve much, but the autocorrelation disappeared, particularly when second order models were estimated.

The long term supply elasticities seem to be small in general, a fact which also corresponds to expectations and earlier studies. The estimation of cross elasticities was not very successful and only one or two variables in addition to the producer price of the product concerned, could be included in the models. The estimation of supply elasticities proved to be sensitive to the inclusion of a new variable or a new observation. This may be due to the small number of observations or due to the rapid change in supply conditions which may be difficult to explain by econometric methods.
\end{abstract}

\section{Introduction}

The purpose of this study is to estimate long term elasticities for agricultural products. Nine products or product groups are included in the analysis and the estimation is based on the data from 1960-1982. Supply elasticities are needed for agricultural policy, e.g. in guiding production by price policy. They are also applied in forecasting.

Supply elasticities for agricultural products have already been estimated in Finland (e.g. Kettunen 1968, Ihamuotila 1972, AalTONEN 1976, HaGgReN 1976, Lehtinen 1976, NEVAla 1976, RYÖKÄs 1982), though mainly using quarterly data which is usually considered to give short term elasticities. Elasticities are not stable, so there is pertinent reason to re-estimate them now and then. This has also been done, but since computer programs make estimation and simultaneous

1 This article is based on a more comprehensive Finnish report of the study by KETTUNEN and RYOKÄs (1984).

Index words: supply function, econometrics, models 
forecasting easy, only few results have been reported. It is, however, advantageous to publish estimates now and then, e.g. for comparative studies. On the other hand, no comprehensive supply analysis has earlier been made in Finland. In this sense this study is also useful.

\section{Long term supply}

Text books define the long term as a period during which all factors of production become variable (TomeK \& RoBinson, 1975). All factors of production then adjust e.g. to the change of a price. It means that the use of labour, capital and land corresponds to the new optimum. If, for instance, pork production is considered, it is easy to figure out that production cannot react to a change in the price of pork during a quarter since more than a year is needed before a change in seminations has caused a change in production. If, in addition, new pig barns induced by the price change are taken into account, a full adjustment requires even a longer time period. In egg production the reaction time is obviously shorter than in pork production, whereas the increase of milk production requires perhaps at least two years to adjust to the new situation. Production decisions are made once a year in plant production, but it can be assumed that they are based on the information from several years. It can be said that it depends on the product concerned how long "the long term" is.

Mathematical assumptions and different models have been used to try to solve the problem. A school example is NerLoves model (1958), which is usually applied for demand analysis but which can be used in supply analysis as well. In general, these models are known as distributed lag models or autoregressive models.

The theory of autoregressive models is large and there is no reason to review it in detail here (see e.g. Box \& JENKINS 1970 or JoHnsTON 1963). These models try to utilize the in- formation of residuals. In the simplest form, the residual may be correlated with itself as follows:

\section{1. $\mathrm{u}_{\mathrm{t}}=\mathrm{r}_{1} \mathrm{u}_{\mathrm{t}-1}+\mathrm{e}_{\mathrm{t}}$,}

where e is normally distributed and free of autocorrelation. A supply function may then be written as follows:

\section{2. $\mathrm{Q}_{1}=\mathrm{f}\left(\mathrm{P}_{11}, \mathrm{P}_{2 \mathrm{t}}, \ldots\right)+\mathrm{r}_{1} \mathrm{u}_{1-1}+\mathrm{e}_{\mathrm{t}}$,}

where the quantity supplied (Q) depends on different prices $\left(\mathrm{P}_{\mathrm{i}}\right)$ and on the residual. This is a first order autoregressive model.

Autocorrelation may also be:

2.3. $u_{t}=r_{1} u_{t-1}+r_{2} u_{t-2}+e_{t}$.

This assumption gives a second order autoregressive model:

$$
\text { 2.4. } \begin{aligned}
& \mathrm{Q}_{\mathrm{t}}=\mathrm{f}\left(\mathrm{P}_{1 \mathrm{t}}, \mathrm{P}_{2 \mathrm{t}}, \ldots\right)+ \\
& \mathrm{r}_{1} \mathrm{u}_{t-1}+\mathrm{r}_{2} \mathrm{u}_{1-2}+\mathrm{e}_{\mathrm{t}} .
\end{aligned}
$$

Both models 2.2. and 2.4. are applied in this study. It depends on the real situation, how meaningful it is to apply these models.

\section{The variables}

The dependent variable used for plant products was the cultivated area, since it can better indicate the result of decision making than the quantities marketed (or produced). The supply of animal products was, however, expressed in quantities (kilograms) except for milk in litres.

Producer prices deflated by the producer price index were the primary explanatory variables. Cost variables also belong to a supply function. Such variables are the cost index for machinery and implements, the price index for fertilizers, the price index for feed and the index of wages and salaries for hired labor in agriculture. Price indices were deflated by the whole sale price index and wages and salaries by the producer price index.

Technological development and some disturbance variables such as weather often 
belong to a supply function. The trend variable $(1,2,3, \ldots)$ was used to depict the technological development. A satisfactory variable for weather was not, however, found in this study.

\section{Estimation and presentation of parameters}

The parameters of the supply functions were estimated by the least squares method. The parameters of autoregressive models were, however, usually estimated by Cochrane-Orcutt method, but other alternatives exist. The maximum likelihood method was tried in some cases, but it did not seem to improve the analysis. However, it has to be noted that this type of experimentation does not give any general proof for or against any method.

Supply elasticities are given in the table below. They have been calculated by applying means of the variables (elasticity $b^{*}{ }_{i}=$ $b_{i}\left(X_{i} / Y\right)$, where $b_{i}$ is the linear regression coefficient of the variable $\mathrm{X}_{\mathrm{i}}$ ). However, the regression coefficient proper is given for the lagged dependent variable $\mathrm{y}_{t-1}$, since it is more meaningful than the elasticity. It is also needed for the calculation of long term elasticities. The $t$-values of the regression coefficients are given in the tables as well as the coefficient of determination $\mathrm{R}^{2}$ (the loss of the degrees of freedom is not taken into account). The tables also include the DurbinWatson statistics d or the Durbin statistics h for the models that have the lagged dependent variable as an explanatory variable since the normal Durbin-Watson test is not then valid.

\section{Milk supply}

Milk production reached its peak in Finland in the middle of the 1960s. The number of dairy cows then started to decline, but the production stayed rather stable for some time. Export difficulties for milk products finally forced the State to apply strong supply restrictions at the end of 1960s. Milk productions fell quite rapidly to a level of $3100-$ 3200 mill. litres at which it has stayed albeit small variations exist.

Supply restrictions have no doubt effected milk production but they cannot be included in the models. The producer price of milk is, of course, the first variable to be included in the milk supply function. In addition, the price of substitutes such as bread grains and meat are normal variables in the supply function. Milk producers have switched to grain or to pork (in some cases to beef) production. The shortage of hired labour has also been a limiting factor in milk production and therefore, the wage of hired labour was also included in the supply function. Another cost factor which was also tried in the model is the price of purchased feed, though it can be assumed that its relevance is not very great since milk production is based mainly on feed produced on the farm. The latest development seems, however, to lead to an ever increasing use of purchased feed for quality reasons and because of the lack of feed.

\subsection{Conventional models}

Supply elasticities for milk given in table 5.1. were obtained by adding a variable stepwise into the model (without any special criteria). The coefficient of determination of the 5 th function is rather high, but the coefficients for grains and feed are illogical. The most interesting of the coefficients is the supply elasticity with respect to the producer price of milk ( 0.23 in the last function). Since there are illogical coefficients in the model, the analysis had to be continued. When only the logical variables were included in the model, the coefficients given in table 5.2. on line 6 were obtained. The elasticities seem to be rather small as can be expected, since milk production changes slowly. 
Table 5.1. Supply elasticities for milk; a linear model for 1961-1982. The t-values of the regression coefficients are given in parenthesis.

\begin{tabular}{|c|c|c|c|c|c|c|c|}
\hline & \multicolumn{4}{|c|}{ Price of } & \multirow[t]{2}{*}{ Wages } & \multirow[t]{2}{*}{$\mathbf{R}^{2}$} & \multirow[t]{2}{*}{ d } \\
\hline & milk & beef & wheat & feed & & & \\
\hline 1. & $\begin{array}{c}-0.65 \\
(3.02)\end{array}$ & & & & & & \\
\hline 2. & $\begin{array}{c}-0.28 \\
(2.86)\end{array}$ & $\begin{array}{r}-0.39 \\
(9.56)\end{array}$ & & & & 0.31 & 0.59 \\
\hline 3. & $\begin{array}{c}0.13 \\
(0.96)\end{array}$ & $\begin{array}{c}-0.18 \\
(2.68)\end{array}$ & $\begin{array}{c}0.18 \\
(3.67)\end{array}$ & & & 0.88 & 1.35 \\
\hline 4. & $\begin{array}{c}0.13 \\
(1.05)\end{array}$ & $\begin{array}{c}-0.15 \\
(2.32)\end{array}$ & $\begin{array}{c}0.18 \\
(4.06)\end{array}$ & $\begin{array}{c}0.14 \\
(1.90)\end{array}$ & & 0.93 & 1.21 \\
\hline 5. & $\begin{array}{c}0.23 \\
(1.41)\end{array}$ & $\begin{array}{r}-0.13 \\
(1.89)\end{array}$ & $\begin{array}{c}0.16 \\
(3.08)\end{array}$ & $\begin{array}{c}0.10 \\
(1.22)\end{array}$ & $\begin{array}{r}-0.044 \\
(0.96)\end{array}$ & $\begin{array}{l}0.94 \\
0.95\end{array}$ & $\begin{array}{l}1.40 \\
1.43\end{array}$ \\
\hline
\end{tabular}

\subsection{Autoregressive models}

The autocorrelation of the residuals of all models led to the use of autoregressive models. However, they brougth rather small changes compared with the basic model 5.2.6. The supply elasticity with respect to milk's own price rose to 0.20. A general feature of the models is that the coefficients are rather stable. The autocorrelation of the residuals, however, disappeared. The coefficient of determination did not, however, rise significantly.

As the residual in figure 1 shows, the estimated model has difficulties to explain the rapid fall in production which took place in 1970 due to field reservation and slaughtering schemes. These ex post -forecasts are also rather erroneous at the latter part of the estimation period. Neither do the autoregressive models give a better fit than the basic model. Economic factors do not always explain all the variation. E.g. the quality of feed has a considerable effect on production but there is insufficient data to test this hypothesis.

\section{Beef}

Beef production is heavily tied to milk production. The number of animals slaughtered depends on the number of calves, and since the number of dairy cows has fallen, the number of animals for beef production has decreased accordingly. The average slaughter weight has, however, risen. Ani-

Table 5.2. Autoregressive models for milk production.

\begin{tabular}{|c|c|c|c|c|c|c|c|}
\hline & \multicolumn{2}{|c|}{ Price of } & \multirow[t]{2}{*}{ Wages } & \multirow[t]{2}{*}{$r_{1}$} & \multirow[t]{2}{*}{$\mathrm{r}_{2}$} & \multirow[t]{2}{*}{$\mathrm{R}^{2}$} & \multirow[t]{2}{*}{ d } \\
\hline & milk & beef & & & & & \\
\hline 6. & $\begin{array}{c}0.14 \\
(0.78)\end{array}$ & $\begin{array}{r}-0.24 \\
(3.70)\end{array}$ & $\begin{array}{r}-0.12 \\
(2.68)\end{array}$ & & & 0.92 & 1.27 \\
\hline 7. & $\begin{array}{c}0.20 \\
(1.12)\end{array}$ & $\begin{array}{r}-0.17 \\
(2.16)\end{array}$ & $\begin{array}{r}-0.15 \\
(2.98)\end{array}$ & $\begin{array}{c}0.93 \\
(2.49)\end{array}$ & & 0.93 & 1.57 \\
\hline 8. & $\begin{array}{c}0.20 \\
(1.20)\end{array}$ & $\begin{array}{r}-0.20 \\
(2.90)\end{array}$ & $\begin{array}{r}-0.15 \\
(3.43)\end{array}$ & $\begin{array}{c}0.57 \\
(2.89)\end{array}$ & $\begin{array}{r}-0.39 \\
(2.01)\end{array}$ & 0.94 & 1.91 \\
\hline
\end{tabular}


Production, mill. litres

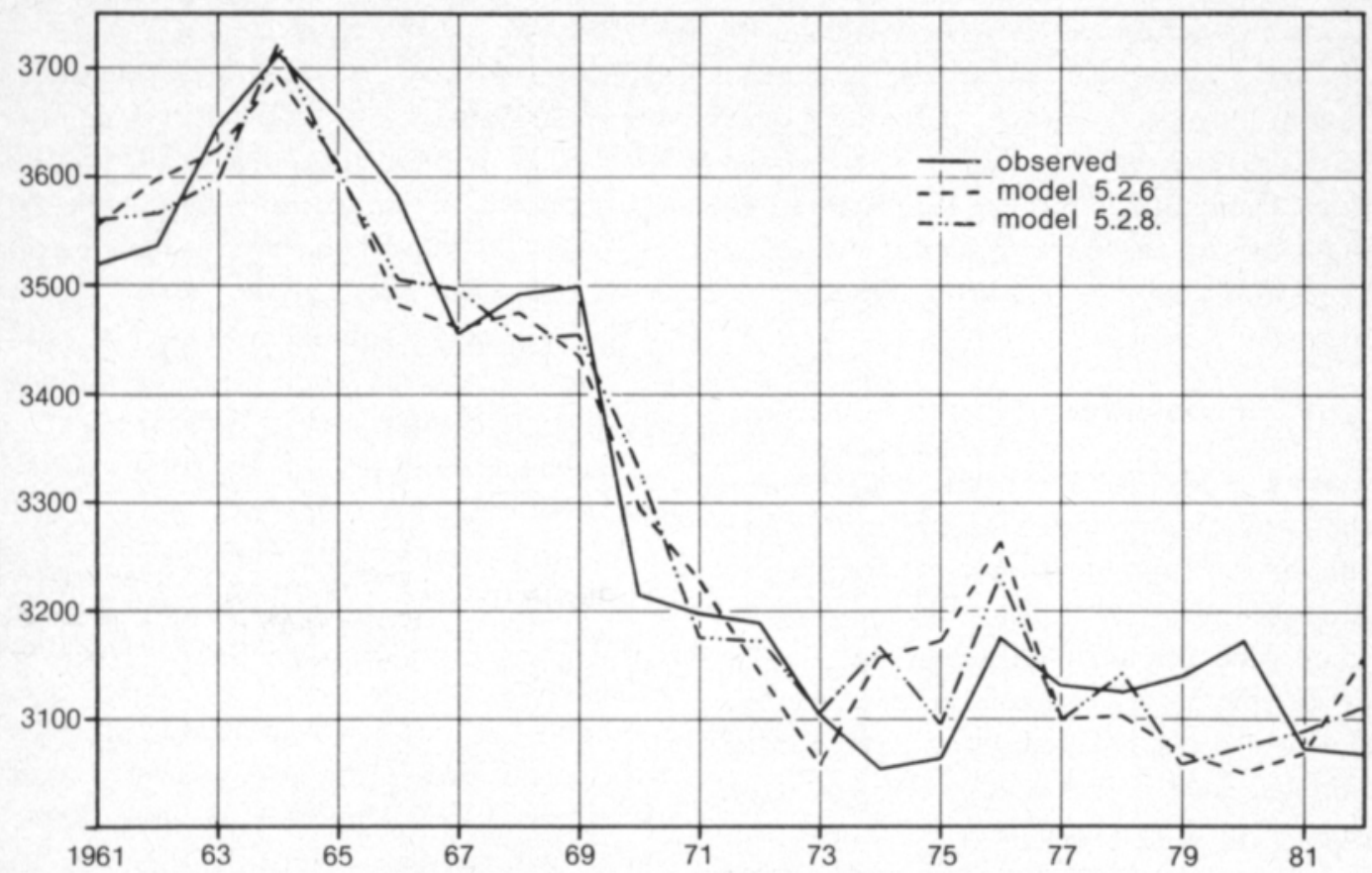

Fig. 1. Milk production in $1961-82$ and ex post forecasts of models 5.2.6 and 5.2.8.

mals are fed more intensively than earlier and the slaughtering of small calves has diminished rapidly. This has enabled the production of beef to grow continuously. According to forecasts, production may not grow any more and it will probably stay at a level of $100-110$ mill. $\mathrm{kg}$ in the future.

Conventional variables such as producer prices of beef and pork as well as the price of feed were used in the supply function for beef. The coefficient of determination is low (table 6.1.), but the estimates are mainly logical. The supply elasticity with respect to the beef price is low, only $0.15-0.18$, nor is the estimate statistically significant. On the other hand, the cross elasticity with respect to the price of pork is high, which is difficult to explain.

Beef production fluctuates quite strongly, which is often a result of variation in feed

Table 6.1. Supply elasticities for beef; a linear model for 1961-1982. The t-values of the regression coefficients are given in parenthesis.

\begin{tabular}{|c|c|c|c|c|c|c|}
\hline & \multicolumn{3}{|c|}{ The price of } & \multirow[t]{2}{*}{$Y_{t-1}$} & \multirow[t]{2}{*}{$\mathrm{R}^{2}$} & \multirow[t]{2}{*}{ d } \\
\hline & beef & pork & feed & & & \\
\hline 1. & $\begin{array}{c}0.15 \\
(0.66)\end{array}$ & $\begin{array}{r}-1.06 \\
(2.47)\end{array}$ & $\begin{array}{r}-0.16 \\
(0.42)\end{array}$ & & 0.54 & 1.39 \\
\hline 2. & $\begin{array}{r}-0.07 \\
(0.34)\end{array}$ & $\begin{array}{r}-0.58 \\
(1.51)\end{array}$ & & $\begin{array}{c}0.58 \\
(3.01)\end{array}$ & 0.69 & 2.33 \\
\hline 3. & $\begin{array}{c}0.18 \\
(0.84)\end{array}$ & $\begin{array}{r}-1.05 \\
(2.50)\end{array}$ & & & 0.53 & 1.39 \\
\hline
\end{tabular}


yield. If the yield is good, animals may be raised heavier and so they come later to the market and production grows. After that supply may decrease due to the countereffect, i.e. fewer animals available for production. These fluctuations are difficult to explain by regression models even if the feed yield would be included in the model.

\section{Pork production}

Pork production has nearly tripled during the estimation period. This may not be a result of the price development, for the real producer price has fallen a little during the same time period. One reason for this increase may be the rationalization of production which has lowered costs. Pork production has also grown due to the shift from milk to pork production.

The supply function again includes the producer price of the pork and the trend variable, which depicts the growth of production but for which it is difficult to find any real variable. The feed price belongs to the supply function as well as the price of competing factors like prices of grains and eggs, and wages from the cost factors.

The first model was estimated by the selective regression analysis and by forcing the producer price of pork into the model. Only the trend variable was then included in the model (function 1 in table 7.1.). The coeffi- cient of determination of this model is rather high, 0.96 .

The price of feed is an important factor in the pork supply. Its elasticity is logical ( -0.17 , function 2$)$ but rather small, and the coefficient is not statistically significant. In any case, this model can be considered as a basic model for pork supply.

The residual is again highly autocorrelated which supports the application of autoregressive models. The elasticities of the coefficients changed a little, e.g. the supply elasticity with respect to the own price fell a little. On the other hand, the elasticity with respect to the price of feed increased a little. The elasticities of model 4 can be considered satisfactory.

Supply for pork has been fairly well studied, particularly using the quarterly data (KetTUNEn 1968). The elasticity with respect to the own price is often of the same size as in this study or about $0.4-0.6$. The results of this study are satisfactory in this sense or they do not deviate much from the earlier studies. It has to be noted again that the estimates of the coefficient are rather sensitive both for changing the variables and the length of time period.

\section{Eggs}

Egg production grew steadily up to 1977 . The overproduction was then about $65 \%$ of

Table 7.1. Supply elasticities for pork; a linear model for 1961-1982. The t-values of the regression coefficients are given in parenthesis.

\begin{tabular}{lccccccc}
\hline No. & $\begin{array}{c}\text { Price of } \\
\text { pork }\end{array}$ & Trend & $\begin{array}{c}\text { Price of } \\
\text { feed }\end{array}$ & $\mathrm{r}_{1}$ & $\mathrm{r}_{2}$ & $\mathrm{R}^{2}$ & $\mathrm{~d}$ \\
\hline 1. & 1.59 & 6.81 & & & & 0.96 & 0.97 \\
& $(1.25)$ & $(10.3)$ & & & & & \\
2. & 0.55 & 6.71 & -0.17 & & & & 0.97 \\
& $(1.14)$ & $(9.73)$ & $(0.65)$ & & & 0.97 & 1.58 \\
3. & 0.44 & 6.58 & -0.14 & 0.50 & & & \\
& $(1.06)$ & $(9.31)$ & $(0.50)$ & $(2.74)$ & & & \\
4. & 0.31 & 6.39 & -0.26 & 0.68 & -0.45 & 0.98 & 1.93 \\
& $(0.81)$ & $(11.2)$ & $(0.91)$ & $(2.59)$ & $(2.34)$ & & \\
\hline
\end{tabular}


consumption and the State had to use strong actions to curtail the production. Some success was achieved in $1977-80$, but after that production has again grown slightly. Since production growth has been linear, it is easy to get good models for egg supply, at least the coefficient of determination is high.

The estimates of elasticities are also satisfactory. The elasticity of supply with respect to the own price is positive though rather small, some $0.1-0.2$. The price of feed also seems to have little effect on egg production, but since the lagged production is included in the model, this variable dominates the estimation and so the effect of other variables is nearly eliminated from the model. Egg production has grown (as pork production) due the fact that former milk producers have chosen eggs as a substitute product on their farms.

Autoregressive models were also applied to egg production. The additional information gained from these models is limited. The autocorrelation of the residuals is, of course, eliminated, but the coefficient of determination does not increase much. The coefficients have, however, about the same size as in the conventional models.

\section{Cereals}

\subsection{Bread grain}

The production of bread grain depends on two factors: the cultivated area and the yield per hectare. It is hard to affect the latter one in the short term, but the yield per hectare depends very greatly on weather conditions. Good examples are the very latest years: the yield perhectare of successive years has varied by up to $31 \%$. One has, of course, some kind of idea about the average yield, although it is difficult to approximate even that because of the great variations.

One can say that farmers' decisions in grain production can be seen in the cultivated area. So we regard them as dependent variables. Economic factors are the first things that come into mind when selecting variables for the production function of bread grain. In addition to its own producer price, we can think of the producer price of feed grain and the producer prices of animal products, although it is difficult to say what product mostly competes with bread grain. The most important of the cost factors are, of course, the prices of fertilizers. Machinery costs were also used as an independent variable.

In the very latest years some special factors have had an effect on bread grain cultivation, but it is difficult to include these factors to the supply model. For example, there were great difficulties in marketing the good crop of 1976, which apparently consideraldy reduced the cultivation areas the following year. Weather conditions have also been very unfavourable for autumn sowing in some years and the cultivation are-

Table 8.1. The supply elasticities for eggs; a linear model for 1961-1982. The t-values of the regression coefficients are given in parenthesis.

\begin{tabular}{lccccccc}
\hline No. & $\begin{array}{c}\text { Price of } \\
\text { eggs }\end{array}$ & $\begin{array}{c}\text { Price of } \\
\text { feed }\end{array}$ & $Y_{t-1}$ & $r_{1}$ & $r_{2}$ & $R^{2}$ & $d$ \\
\hline 1. & 0.11 & -0.16 & 0.99 & & & 0.94 & 1.52 \\
& $(0.45)$ & $(0.77)$ & $(5.43)$ & & & & \\
2. & 0.03 & 0.15 & 0.93 & 0.23 & & 0.95 & 1.70 \\
& $(0.11)$ & $(0.65)$ & $(4.72)$ & $(1.11)$ & & & \\
3. & 0.18 & -0.05 & 1.06 & 0.28 & -0.50 & 0.96 & 1.75 \\
& $(0.86)$ & $(0.24)$ & $(6.64)$ & $(1.56)$ & $(2.74)$ & & \\
\hline
\end{tabular}


Table 9.1. The supply elasticities for bread grain; a linear model for 1961-82. The t-values of the regression coefficients are given in parentheses.

\begin{tabular}{lccccc}
\hline & \multicolumn{3}{c}{ Price of } & $\mathrm{R}^{2}$ & $\mathrm{~d}$ \\
\cline { 2 - 4 } & grain & $\begin{array}{c}\text { ferti- } \\
\text { lizers }\end{array}$ & $\begin{array}{c}\text { sugar } \\
\text { beet }\end{array}$ & & \\
\hline 1. & 0.87 & & & 0.641 & 1.39 \\
& $(5.98)$ & & & & \\
2. & 0.85 & -0.80 & & 0.704 & 1.11 \\
& $(6.26)$ & $(2.00)$ & & & \\
3. & 0.16 & -1.03 & 0.651 & 0.747 & 1.34 \\
& $(0.39)$ & $(2.57)$ & $(1.76)$ & & \\
\hline
\end{tabular}

as of rye and winter wheat may therefore have been reduced.

The decision making process concerning grain sowing apparently takes a long time. The price information competes with the experiences farmers get from weather. One can assume, therefore, that farmers take into consideration the information of several years. Consequently, the use of autoreggressive models seems very reasonable, especially in connection with bread grain models. Lagged variables can well be used as independent variables and the residual models can well be included in the research models. When using customary models, only the producer pice of grain and the price of fertilizers acted according to the assumptions (models 1 and 2), that is to say their coefficients had the right sign. In table 9.1. there is also a model, which has the price of sugar beet as an independent variable, because it can be assumed that sugar beet competes with bread grain, even very intensively. However, the model gives no support to this assumption.

\subsection{Feed grain}

It is difficult to explain how the sowing area of feed grain is determined, because part of the feed production of a farm goes directly to animal husbandry, and only part of it is marketed. Economic factors, such as the prices of the competing products, affect the part that is marketed. On the other hand, the price of feed grain has hardly any effect on the feed used on a farm: feed production depends on animal husbandry. This is why the dependence of feed production on some seemingly competing product, such as pork price can be either positive or negative. The sign depends on the purpose of feed production: it is either used on a farm or sold. On the other hand, feed grain has been substituted for hay in cattle feeding. This can be seen as a smaller area used for hay, whereas the cultivation area of feed grain has continually increased.

The results of estimations support the assumption that there are difficulties in calculating the price elasticity of feed grain. It is negative in all models (table 9.2.). Estimations of cross elasticities cause difficulties too. The reason for this may be that because feed grain has a very central role in our agriculture, it is probably not regulated by price, but by other factors. However, model 4 (table 9.2) is of interest because of the coefficients of machinery costs and the price of wheat. It might also be thought that the elasticity with respect to the price of pork would be positive, because an increase in pork production means more need for feed, and so the quantity of feed produced on a farm can increase. In the same way, it might be thought, that an increase in the price of barley would decrease the production of pork and also the cultivation of barley for feed.

This kind of deduction can rather be interpreted as an effort to explain a poor result of the estimation than a description of the real situation. The best explanation for the illogical results most often is the weakness of the econometric methods.

\section{Sugar beet, oil plants and potatoes}

The estimation of the supply elasticities of sugar beet turned out to be difficult. The 
Table 9.2. Supply elasticities of feed grain; a linear model for years $1961-82$. The t-values of the regression coefficients are given in parantheses.

\begin{tabular}{|c|c|c|c|c|c|c|c|}
\hline & \multicolumn{3}{|c|}{ Price of } & \multirow{2}{*}{$\begin{array}{l}\text { Machinery } \\
\text { costs }\end{array}$} & \multirow{2}{*}{$\begin{array}{l}\text { The trend } \\
\text { variable }\end{array}$} & \multirow[t]{2}{*}{$\mathbf{R}^{2}$} & \multirow[t]{2}{*}{ d } \\
\hline & barley & pork & wheat & & & & \\
\hline 1. & $\begin{array}{c}-0.62 \\
(5.81)\end{array}$ & $\begin{array}{c}-0.24 \\
(0.89)\end{array}$ & & & & 0.87 & 1.17 \\
\hline 2. & $\begin{array}{c}-0.45 \\
(4.05)\end{array}$ & & & & $\begin{array}{c}7.52 \\
(2.47)\end{array}$ & 0.90 & 1.03 \\
\hline 3. & $\begin{array}{c}-0.25 \\
(1.17)\end{array}$ & $\begin{array}{r}-0.17 \\
(0.64)\end{array}$ & $\begin{array}{r}-0.29 \\
(1.97)\end{array}$ & & & 0.90 & 1.18 \\
\hline 4. & $\begin{array}{c}-0.35 \\
(1.80)\end{array}$ & $\begin{array}{c}0.65 \\
(1.63)\end{array}$ & $\begin{array}{r}-0.16 \\
(1.05)\end{array}$ & $\begin{array}{r}-0.44 \\
(1.64)\end{array}$ & $\begin{array}{l}14.18 \\
(2.47)\end{array}$ & 0.93 & 1.49 \\
\hline
\end{tabular}

elasticity with respect to producer price usually became negative. The reason for this may simply be that cultivation area grew rather steadily during the whole of the $70 \mathrm{~s}$, although the real price went down. One could still obtain a logical result by changing the observation period.

The cultivation of sugar beet is based on contract production, which is regulated by the quotas determined by the State. According to the sugar law, the producer price of sugar beet is paid in full only within the quota, and the rest of the production gets a lower price. In the past few years, the quota has been 850 million kilos. This is why we can assume, that the price of sugar has not caused the increase in the cultivation area.

The cultivation of oil plants increased very rapidly during the 1970 s. The State has supported the cultivation of rape and turnip rape in order to rise the self-sufficiency rate of both vegetable oil and coarse grain. It is possible to affect it by price policy. Speaking about oil we are already self-sufficient, although it must be added that the domestic oil is not fully suitable for the margarine industry, so vegetable oil is imported and exported at the same time. Self-sufficiency in coarse grain, has not yet been reached, so protein concentrates are still imported.

Estimations succeeded rather well with oil plants, when the lagged cultivation area was taken into the model. Supply elasticity with respect to price is, however, rather small. In the Nerlove model the lagged area seems to dominate the estimation, which is rather natural because of the trend variable.

The production of potatoes has decreased rather steadily during the whole observation period. The reason is probably the decrease

Table 10.1. Supply elasticities for sugar beet, oil plants and potatoes; a linear model for 1961-82. The t-values of the regression coefficients are given in parentheses.

\begin{tabular}{lcccccc}
\hline & $\begin{array}{c}\text { Price of } \\
\text { product }\end{array}$ & $\mathrm{Y}_{t-1}$ & Trend & $\begin{array}{c}\text { Price of } \\
\text { wheat }\end{array}$ & $\mathrm{R}^{2}$ & $\mathrm{~d}$ \\
\hline Sugar beet ${ }^{\prime}$ & 0.34 & 0.83 & 1.12 & & 0.91 \\
& $(0.49)$ & $(5.51)$ & $(2.31)$ & & -0.40 & 0.92 \\
Oil plants & 0.14 & 1.08 & & $(0.62)$ & 3.00 \\
Potato & $(0.18)$ & $(11.5)$ & & & 0.93 \\
& 0.12 & $(10.6)$ & & & 2.15 \\
\hline
\end{tabular}

observation years $1964-79$ 
in consumption. It can be assumed that the production of potatoes will adapt to the consumption, because there has been no export. Potatoes are also used for non-food purposes, such as production of starch. Earlier potatoes were also used for fodder, but this use is nowadays already very small.

The estimation of the supply functions of potatoes has usually turned out to be difficult. The reason for this is probably the fact that a rather good deal of potato production has been and still is used on the farm (AALTONEN 1976). The commercial production of potatoes has had difficulties because of the fact that there is no organized commerce. Plant diseases have also disturbed the cultivation of potatoes. It is difficult to put this kind of factors in the model even if they were the most important factors in potato production.

\section{Summary}

The greatest problem in estimating the supply elasticities has been the instability of the coefficients. The reason for this is the small number of observations. On the other hand, the data does not fulfill all the assumptions that are required for good data. One of the most usual deficiencies in time series data is the small variation of the values of variables and the intercorrelation between variables. This is why the inclusion or exclusion of an observation may have a great effect on the results.

Table 13.1. was compiled by using subjective judgement; it is a summary of the best supply elasticities with respect to the producer price of the product and of other products. Of the cost factors, the table only contains fodder and machine costs. The elasticities presented here are meant for long term forecasting, where only few variables can be used, first of all prices and some selected cost factors.

It is important to take into account the changes in price relations in forecasting. For example, long term consumption forecasts are usually based only on income elasticity and income development. Afterwards it has been possible to conclude that mistakes in forecasting were due to the change in price relations. There is the same danger in supply forecasts. It is difficult to forecast price changes, but some assumptions about them can be made.

Table 13.1. only contains one or two elasticities for each product. This is due to the fact that estimation did not produce multivariable models that would be logical or otherwise reasonable. Some elasticities are therefore lacking, e.g. the price of feed has some kind of effect on both milk and beef production. Likewise, the price of fertilizers affects cultivation of all plants to some extent. It must be added, however, that table 13.1. does not include all the coefficients of each model. The rest are in the tables of the text.

Supply elasticity with respect to the own price of each product is usually small. An exception is bread grain, the supply elasticity of which $(0.85)$ can be too high. Correspondingly, the elasticity of supply of bread grain with respect to the price of fertilizers is also large. Estimation, gave often elasticities which were logical (their signs were right), but their absolute values were too big. Application of a separate elasticity is then not meaningful, but one has to use the model as a whole (e.g. for forecasting).

In conclusion, it must be emphasized that the elasticities presented in this publication are meant for long term forecasting. If one wants to make short term forecasts, the best way is to estimate the model once again, using the latest data and to base the forecasts on that model. In doing so one can use more variables than those in table 13.3.

Acknowledgements. I am grateful to Mikko Ryőkăs for assisting in estimating the parameters of the models and for preparing the Finnish publication on which this paper is based. I wish also to thank other staff members of the institute for helping to prepare this article. 
Table 13.1. Summary of the supply elasticities.

\begin{tabular}{|c|c|c|c|c|c|c|c|c|c|}
\hline \multirow[t]{2}{*}{ Price } & \multicolumn{9}{|c|}{ Product } \\
\hline & Milk & Beef & Pork & Eggs & $\begin{array}{c}\text { Bread } \\
\text { grain }\end{array}$ & $\begin{array}{l}\text { Feed } \\
\text { grain }\end{array}$ & $\begin{array}{c}\text { Sugar } \\
\text { beet }\end{array}$ & $\begin{array}{c}\text { Oil } \\
\text { plants }\end{array}$ & Potato \\
\hline Milk & 0.20 & & & & & & & & \\
\hline Beef & -0.17 & 0.15 & & & & & & & \\
\hline Pork & & -1.06 & 0.55 & & & & & & \\
\hline Eggs & & & & 0.11 & & & & & \\
\hline Wheat & & & & & 0.85 & -0.07 & & -0.40 & \\
\hline Barley & & & & & & -0.09 & & & \\
\hline Sugar beet & & & & & & & 0.34 & & \\
\hline Turnip rape & & & & & & & & 0.14 & \\
\hline Potato & & & & & & & & & 0.12 \\
\hline Fertilizers & & & & & -0.80 & & & & \\
\hline Feed - & -- & -- & -0.17 & -0.16 & -- & -- & -- & --- & -- \\
\hline Model' & 5.3 .8 & 6.1 .1 & 7.1 .2 & 8.1 .1 & 9.1 .2 & 9.4 .6 & 10.1 .1 & 11.1 .1 & 12.1 .1 \\
\hline
\end{tabular}

' See the corresponding table.

\section{References}

Aaltonen, S. 1976. Perunan tarjonta, hinnanmuodostus ja kysyntă Suomessa vuosina 1952/53-1972/73. Maatalouden taloudellisen tutkimuslaitoksen tiedonantoja no. 38,$2 ; 50$ p.

Box, G. \& Jenkins, G. 1970. Time Series Analysis. San Fransisco, $553 \mathrm{p}$.

Haggren, E. 1976. Maamme leipăvilja-alan vaihtelu vuosina 1953-1973. Maatalouden taloudellisen tutkimuslaitoksen tiedonantoja no. $38,1,44$ p.

ІнамиотILA, R. 1972. Leipäviljan tarjonnasta ja tarjontaan vaikuttavista tekijöistä Suomessa vuosina 1951-1970. (Summary: On Bread Grain Supply Functions in Finland in 1951-70). Maatalouden taloudellisen tutkimuslaitoksen julkaisuja no. 26, 60 p.

Johston, J. 1963. Econometric Methods. New York, $437 \mathrm{p}$.

Kettunen, L. 1968. Demand and Supply of Pork and Beef in Finland. Maatalouden taloudellisen tutkimuslaitoksen julkaisuja no. 11, 93 p.

KetTUNEN, L. ja RYoKĀs, M. 1984. Maataloustuotteiden pitkăn aikavälin tarjontafunktiot. Maatalouden ta- loudellisen tutkimuslaitoksen tiedonantoja no. 105, $36 \mathrm{p}$.

LEHTINEN, R. 1976. Öljykasvien tarjontaan vaikuttavista tekijöistă ja tuotannon laajentamismahdollisuuksista Suomessa. Maatalouspolitiikan pro gradu -tutkielma, Helsingin yliopisto. 96 p.

Nerlove, M. 1958. Distributed Lags and Estimation of Long-run Elasticities: Theoretical Considerations. Journal of Farm Economics, Vol. 40, No 2, May 1958.

Neval.a, M. 1976. An Econometric Model for the Finnish Egg Industry. Selostus: Suomen kananmunasektoria kuvaava ekonometrinen malli. Maataloustieteellinen aikakauskirja no. 48: 427-521.

RYÖKĀs, M. 1982. Maatalouden tarjontajoustot Suomessa ja niiden soveltaminen maataloussektorin suunnittelu- ja ennustemalliin. Maatalouspolitiikan pro gradu -tutkielma, Helsingin yliopisto, 77 p.

Tomek, W. \& Robinson, K. 1975. Agricultural Product Prices. Ithaca 1975, $376 \mathrm{p}$.

Ms received May 16, 1984 


\section{SELOSTUS}

\section{Maataloustuotteiden pitkän aikavälin tarjontajoustot}

\section{Lauri Kettunen}

Maatalouden taloudellinen tutkimuslaitos,

Luutnantintie 13, 00410 Helsinki 41

Maataloustuotteiden pitkän aikavälin tarjontajoustoja tarvitaan mm. ennustamiseen ja maatalouspolitiikan suunnitteluun. Vaikka tarjonta-analyyseja onkin tehty runsaasti maassamme, tarjontajoustoista ei ole yhtenäistã tutkimusta. Tämä puute oli lăhtőkohtana tăssã artikkelissa raportoidulle tutkimukselle.

Tarjontajoustot estimoitiin aluksi tavanomaisella pienimmän neliösumman menetelmällä, mutta koska residuaalit olivat usein autokorreloituneet, sovellettiin myös autoregressiivisiă malleja, joiden parametrien esti- mointiin on käytettăvissä valmiita kirjasto-ohjelmia. Niiden avulla saatiin autokorrelaatio poistetuksi, mutta mallien selitysaste ei kuitenkaan noussut kovin paljon. Autoregressiivisten mallien käyttöă on kuitenkin syytă suositella esim. estimoitaessa tarjontamalleja ennustamista varten.

Tutkimustuloksia on esitelty laajemmin KETTUSEN ja RYÖKÄKSEN julkaisussa: Maataloustuotteiden pitkän aikavälin tarjontafunktiot, Maat. tal. tutk.l. tied. No 105. 